\title{
Inhibition Studies of Purple Acid Phosphatases: Implications for the Catalytic Mechanism
}

\author{
Tristan W. Elliott, Nataša Mitić, Lawrence R. Gahan, Luke W. Guddat and Gerhard Schenk* \\ School of Molecular and Microbial Sciences, The University of Queensland, St. Lucia, QLD 4072, Australia
}

\begin{abstract}
Fosfatases ácidas púrpuras (PAP) pertencem à família das metalo-hidrolases binucleares que catalisam a hidrólise de um grande grupo de substratos fosfoésteres em $\mathrm{pH}$ ácido. Apesar dos seus sítios ativos serem estruturamente conservados as PAP apresentam versatilidade mecanística. Neste trabalho são investigados alguns aspectos do mecanismo catalítico de duas PAP, usando os inibidores vanadato e fluoreto como sondas. Enquanto as magnitudes das constantes de inibição das duas enzimas pelo vanadato são semelhantes, as enzimas diferem com relação ao modo de inibição;

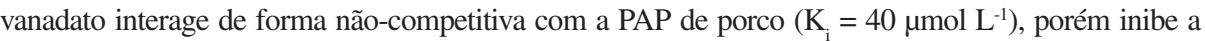

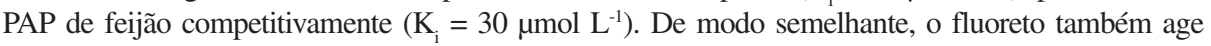
como inibidor competitivo da PAP de feijão, independentemente do $\mathrm{pH}$, enquanto que o fluoreto simplesmente interage com o complexo formado pela enzima de porco e seu substrato(PAPsubstrato) em $\mathrm{pH}$ baixo e inibe de forma não competitiva esta enzima em $\mathrm{pH}$ mais alto, independentemente da composição do íon metálico. Além disso, enquanto a inibição pelo fluoreto se dá através da interação lenta com a PAP de porco, ele se liga rapidamente ao sítio catalítico da enzima do feijão. Visto que se propõe que o vanadato e o fluoreto mimetizem o estado de transição e o nucleófilo, respectivamente, as diferenças observadas na cinética de inibição indicam sutis, porém distintas diferenças no mecanismo de reação destas enzimas.
\end{abstract}

Purple acid phosphatases (PAPs) belong to the family of binuclear metallohydrolases and catalyse the hydrolysis of a large group of phosphoester substrates at acidic $\mathrm{pH}$. Despite structural conservation in their active sites PAPs appear to display mechanistic versatility. Here, aspects of the catalytic mechanism of two PAPs are investigated using the inhibitors vanadate and fluoride as probes. While the magnitude of their vanadate inhibition constants are similar the two enzymes differ with respect to the mode of inhibition; vanadate interacts in a non-competitive fashion with pig PAP $\left(\mathrm{K}_{\mathrm{i}}=40\right.$ $\left.\mu \mathrm{mol} \mathrm{L}{ }^{-1}\right)$ while it inhibits red kidney bean PAP competitively $\left(\mathrm{K}_{\mathrm{i}}=30 \mu \mathrm{mol} \mathrm{L} \mathrm{L}^{-1}\right)$. Similarly, fluoride also acts as a competitive inhibitor for red kidney bean PAP, independent of $\mathrm{pH}$, while the inhibition of pig PAP by fluoride is uncompetitive at low $\mathrm{pH}$ and non-competitive at higher $\mathrm{pH}$, independent of metal ion composition. Furthermore, while fluoride acts as a slow-binding inhibitor in pig PAP it binds rapidly to the catalytic site of the red kidney bean enzyme. Since vanadate and fluoride are proposed to act as transition state and nucleophile mimics, respectively, the observed differences in inhibition kinetics indicate subtle but distinct variations in the reaction mechanism of these enzymes.

Keywords: purple acid phosphatase, catalytic mechanism, kinetics, enzyme inhibition

\section{Introduction}

Purple acid phosphatases (PAPs) belong to the family of binuclear metallohydrolases, with members differing widely with respect to physicochemical properties, tissue localisation and proposed biological function. ${ }^{1,2}$ The characteristic purple colour of these enzymes is due to a charge transfer transition between a ligand (tyrosinate) donor orbital and an acceptor orbital on the ferric ion. ${ }^{1,3,4}$ PAPs catalyse the hydrolysis of a variety of phosphorylated

*e-mail: schenk@uq.edu.au substrates at acidic to neutral $\mathrm{pH}$, and have been identified in, and characterised from animal, plant and fungal sources. ${ }^{5-8}$ The enzyme extracted from mammalian organisms is a 35 $\mathrm{kDa}$ monomer and contains a redox-active $\mathrm{Fe}^{\mathrm{III}}-\mathrm{Fe}^{\mathrm{III} / \mathrm{II}}$ centre. ${ }^{9}$ In contrast, plant PAPs are homodimeric with a molecular mass of $110 \mathrm{kDa}$ and redox-inactive $\mathrm{Fe}^{\mathrm{III}}-\mathrm{Zn}^{\mathrm{II}}$ or Fe $^{\text {III- }}-\mathrm{Mn}^{\mathrm{II}}$ centres. ${ }^{10-12}$

Plant and mammalian PAPs have very similar geometries at the catalytically relevant active site with all seven metal ion-coordinating residues being invariant. ${ }^{1,6,13-18}$ Additional residues that play important roles in various aspects of catalysis are also well 
conserved, including the proposed proton donor to the leaving group (His296 and His195 in red kidney bean and pig PAP, respectively). ${ }^{13-18}$ The observations that PAPs from different organisms have similar $\mathrm{K}_{\mathrm{m}}$ values for a variety of substrates and are inhibited to a similar extent by inorganic phosphate also illustrate the structural similarity of the active sites of different PAPs. ${ }^{10,11,19-21}$

The inhibition of reactivity by a range of antagonists is a common method to investigate an enzyme's catalytic mechanism; additionally such a study may provide valuable information and guidance for the design and development of specific and potent drugs. PAPs from mammalian organisms have been shown to play an integral part in bone metabolism, and an increase in PAP activity is directly linked to osteoporosis, ${ }^{5,22}$ making this enzyme a major target for the development of anti-osteoporotic chemotherapeutics. ${ }^{21}$ For metallohydrolases, fluoride and vanadate are known inhibitors which have been shown to coordinate directly to the metal ion(s) in the active site and thus interfere with catalytic turnover. ${ }^{1,20,23-28}$ The two inhibitors are likely to affect different aspects of catalysis and hence may provide insight into different steps of the reaction mechanism.

The ability of fluoride to readily replace nucleophilic hydroxide groups can provide $(i)$ an insight into the number of labile water/hydroxide binding sites in the active site, and (ii) the role of the terminally bound or bridging hydroxides in the reaction mechanism. ${ }^{26,29}$ Fluoride, a well established osteogenic agent which promotes osteoblastic proliferation and differentiation at clinically relevant concentrations, inhibits animal PAPs in a pH-dependent manner. The mode of inhibition of the FeZn derivative of bovine spleen PAP changes from uncompetitive at $\mathrm{pH} 5.0\left(\mathrm{~K}_{\text {iuc }}=0.2 \mathrm{mmol} \mathrm{L}^{-1}\right)$ to noncompetitive at pH $6.5\left(\mathrm{~K}_{\text {iuc }} \approx 2 \mathrm{mmol} \mathrm{L}^{-1} ; \mathrm{K}_{\mathrm{ic}} \approx 3.4 \mathrm{mmol}\right.$ $\left.\mathrm{L}^{-1}\right){ }^{24}$ In contrast, for human PAP it has recently been shown that the mode of inhibition is only $\mathrm{pH}$ dependent for the enzyme that is proteolytically cleaved in a mobile loop in the vicinity of the active site, changing from nonto uncompetitive as the $\mathrm{pH}$ is raised; for the intact form fluoride acts as a non-competitive inhibitor at $\mathrm{pH} 3.30$ and $4.90 .^{20}$

Stable five-coordinate oxovanadium species are a suitable mimic for the five-coordinate phosphoryl transition state proposed for a number of phosphorolytic reactions..$^{30,31}$ Previously, it was reported that the inhibition constant of pig PAP for vanadate is $40 \mu \mathrm{mol} \mathrm{L}{ }^{-1}$ at $\mathrm{pH} 5.5$, and the mode of binding of the inhibitor is noncompetitive. ${ }^{23}$ The di-zinc alkaline phosphatase from Escherichia coli is inhibited by vanadate with similar efficiency $\left(\mathrm{K}_{\mathrm{i}}=12 \mu \mathrm{mol} \mathrm{L} \mathrm{L}^{-1}\right.$ at $\left.\mathrm{pH} 8.0\right)$, and the crystal structure of the enzyme-inhibitor complex shows that vanadate binds in a penta-coordinate geometry to the active site with three of its oxygen atoms coordinating the two metal ions in the active site in a tripodal arrangement (Figure 1)..$^{25}$

In this work, the inhibitory effects of fluoride and vanadate on the activity of red kidney bean and pig PAP are assessed and compared with those measured for other PAPs. The mechanistic implications of these studies are also discussed.

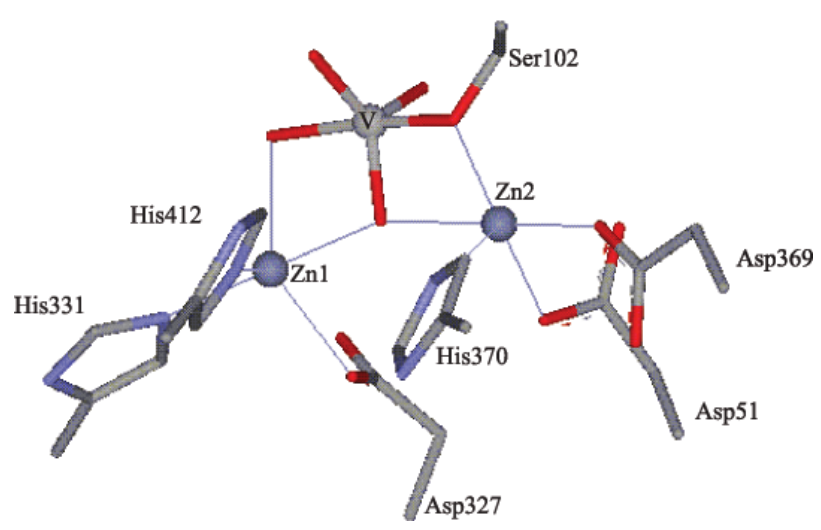

Figure 1. Active site of E. coli alkaline phosphatase with bound vanadate. Vanadate is five-coordinate and interacts with three of its oxygen atoms with the binuclear metal centre. In addition, residue Ser102 forms a covalent bond with the inhibitor.

\section{Experimental}

\section{Materials}

All solutions were prepared with analytical grade reagents purchased from Sigma, Merck or Fluka.

\section{Protein purification}

Pig PAP was extracted from the uterine fluid of a pregnant sow and the plant PAP was purified from the pulp of red kidney beans as described elsewhere..$^{10,32}$ In brief, both enzymes underwent an initial ion-exchange chromatography step using CM-cellulose resin, followed by gel filtration on a Sephadex G-75 (pig PAP) or Sephadex S-300 column (red kidney bean PAP). Purified pig PAP was stored at $-20{ }^{\circ} \mathrm{C}$ in $100 \mathrm{mmol} \mathrm{L} \mathrm{L}^{-1}$ acetate buffer at $\mathrm{pH} 4.9$ and red kidney bean PAP was stored in 0.5 mol L-1 $\mathrm{NaCl}$ at $4{ }^{\circ} \mathrm{C}$ until further use. Protein concentrations were determined by measuring the absorbance at $280 \mathrm{~nm}$ using the specific extinction of 1.41 for a $1 \mathrm{mg} \mathrm{mL}^{-1}$ solution $\left(28.6 \mu \mathrm{mol} \mathrm{L}^{-1}\right)$ of pig PAP and 2.1 for a $1 \mathrm{mg} \mathrm{mL}^{-1}$ solution $\left(9.1 \mu \mathrm{mol} \mathrm{L}^{-1}\right)$ of rkbPAP. SDS-Page analysis confirmed the purity of the enzymes. 


\section{${ }^{51}$ V Nuclear Magnetic Resonance Spectroscopy}

The ${ }^{51} \mathrm{~V}$ NMR spectra were recorded at $132 \mathrm{MHz}$ with a Bruker Avance 400MHz NMR. All experiments were conducted at $25^{\circ} \mathrm{C}$ with a spectrum width of $8064 \mathrm{~Hz}$, no relaxation delay, a $90^{\circ}$ pulse angle and an accumulation time of $0.2 \mathrm{~s}$. The chemical shifts reported are relative to the external reference $\left(\mathrm{VOCl}_{3} ; 0 \mathrm{ppm}\right)$.

Vanadate stock solutions were prepared by boiling a concentrated solution $\left(200 \mathrm{mmol} \mathrm{L}^{-1}\right)$ of $(\mathrm{Na})_{3} \mathrm{VO}_{4}$ in deionised water (MilliQ) for $10 \mathrm{~min}$ to maximise the presence of the $\mathrm{VO}_{4}$ monomers. ${ }^{23}$ Small volumes from these stocks were added to $0.1 \mathrm{~mol} \mathrm{~L}^{-1} \mathrm{MES}$ buffer, $\mathrm{pH}$ 6.2 , containing $0.2 \mathrm{~mol} \mathrm{~L}^{-1} \mathrm{KCl}$ and $10 \%(\mathrm{v} / \mathrm{v}) \mathrm{D}_{2} \mathrm{O}$ to generate final vanadate concentrations of 0.025-2.00 mmol $\mathrm{L}^{-1}$. These solutions matched the conditions employed in the kinetics experiments (see below). Relative amounts of the individual species were obtained by peak integration, and total concentrations were calculated by multiplication of the relative amounts by the total vanadate concentration in solution (Figure 2).

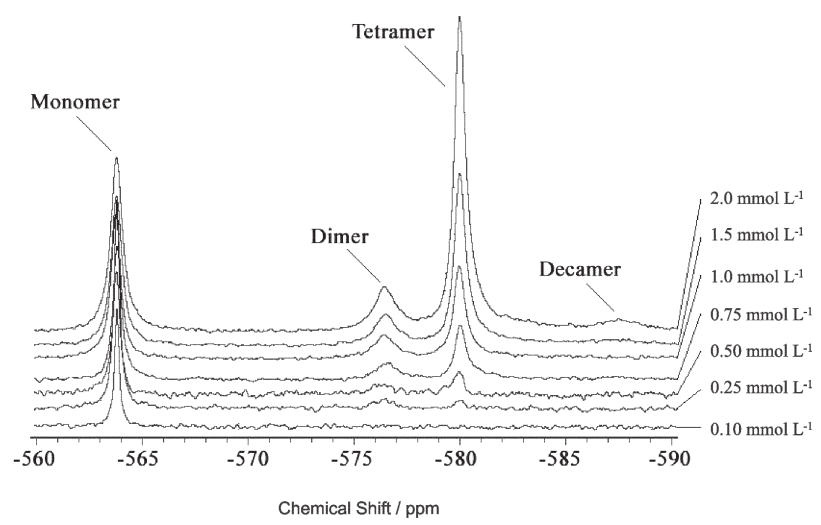

Figure 2. ${ }^{51} \mathrm{~V}$ NMR analysis of vanadate speciation under conditions identical to those employed in the enzymatic assays. The sample solutions contained total vanadate concentrations ranging from $0.1-2.0 \mathrm{mmol}$ $\mathrm{L}^{-1}$ (as indicated on the right side) in $0.1 \mathrm{~mol} \mathrm{~L}^{-1} \mathrm{MES}$ buffer at $\mathrm{pH} 6.2$ with $0.2 \mathrm{~mol} \mathrm{~L}^{-1} \mathrm{KCl}$ and $10 \%(\mathrm{v} / \mathrm{v}) \mathrm{D}_{2} \mathrm{O}$. The data were measured at 139$\mathrm{MHz}$ at $25^{\circ} \mathrm{C}$.

\section{Enzyme kinetics}

The rates of product formation by pig and red kidney bean PAPs were determined at $25^{\circ} \mathrm{C}$ using a continuous assay with para-nitrophenol phosphate ( $p$-NPP) as substrate. Measurements were carried out at $\mathrm{pH} 4.90$ (0.1 mol L-1 acetate buffer, $\left.0.2 \mathrm{~mol} \mathrm{~L}^{-1} \mathrm{KCl}\right)$ or pH $6.20(0.1$ mol L-1 MES buffer, $0.2 \mathrm{~mol} \mathrm{~L}^{-1} \mathrm{KCl}$ ), the respective $\mathrm{pH}$ optima for pig and red kidney bean PAPs. ${ }^{21,33}$ Product ( $p$ NP) formation was monitored at $\lambda=390 \mathrm{~nm}$ with $\Delta \varepsilon_{390}=$ $342.9 \mathrm{~mol}^{-1} \mathrm{~L} \mathrm{~cm}^{-1}$ and $1834.4 \mathrm{~mol}^{-1} \mathrm{~L} \mathrm{~cm}^{-1}$ at $\mathrm{pH} 4.90$ and pH 6.20, respectively. Substrate concentrations ranged from 1 to $15 \mathrm{mmol} \mathrm{L}^{-1}$. Enzyme concentrations in steadystate assays were $20 \mathrm{nmol} \mathrm{L}^{-1}$ and $2 \mathrm{nmol} \mathrm{L}^{-1}$ for the two enzymes, respectively, and $50 \mathrm{nmol} \mathrm{L}^{-1}$ in stopped-flow measurements. Concentrations of the inhibitors ranged from 0.1 to $25 \mathrm{mmol} \mathrm{L}^{-1}(\mathrm{NaF})$ and 0.01 to $0.5 \mathrm{mmol} \mathrm{L}^{-1}$ $\left(\mathrm{Na}_{3} \mathrm{VO}_{4}\right)$.

All steady-state assays were performed with a Varian Cary50 UV-Vis spectrophotometer with $1 \mathrm{~cm}$ path length quartz cuvettes. The possibility of measurable pre-steady state reactions was assessed by stopped-flow kinetics using an Applied Photophysics SX18 stopped-flow spectrometer with a $1 \mathrm{~cm}$ path length. The data were analysed using GraphPad Prism 4.0 software or WinCurveFit (Kevin Raner software). The catalytic parameters were evaluated by nonlinear regression using the Michaelis-Menten (equation 1) or general inhibition equation (equation 2), respectively:

$$
\begin{aligned}
& v=\frac{V_{\max }[S]}{[S]+K_{m}} \\
& v=\frac{V_{\max }[S]}{[S]\left(1+\frac{[I]}{K_{i u c}}\right)+K_{m}\left(1+\frac{[I]}{K_{i c}}\right)}
\end{aligned}
$$

Here, $\mathrm{V}_{\max }\left(=\mathrm{k}_{\mathrm{cat}}[\mathrm{E}]\right)$ and $\mathrm{K}_{\mathrm{m}}$ are the maximum rate and the Michaelis constant, [S] and [I] the concentrations of substrate and inhibitor, and $\mathrm{K}_{\mathrm{ic}}$ and $\mathrm{K}_{\mathrm{iuc}}$ the equilibrium dissociation constants for competitive and uncompetitive inhibitor binding, respectively. ${ }^{34}$ Pre-steady state data were analysed with equation 3 , where $\mathrm{A}_{0}$ and $\mathrm{A}_{\mathrm{t}}$ represent the absorbance (at $390 \mathrm{~nm}$ ) of product at time 0 and $t, v_{i}$ and $\mathrm{v}_{\mathrm{f}}$ the rates in the initial and final (steady state) phases of the reaction, and $\mathrm{k}_{\mathrm{obs}}$ the rate constant for the change from the fast initial rate to the slower final rate. ${ }^{24,35,36}$

$A_{t}=A_{0}+v_{f} t+\frac{\left(v_{i}-v_{f}\right)\left(1-e^{-k_{o b s} t}\right)}{k_{o b s}}$

\section{Results and Discussion}

The specific activity of pig PAP at $\mathrm{pH} 4.9$ (optimum $\mathrm{pH})$ and $\mathrm{pH} 6.2$ is $635 \mathrm{U} \mathrm{mg}^{-1}\left(\mathrm{k}_{\text {cat }}=370 \mathrm{~s}^{-1}\right)$ and $371 \mathrm{U}$ $\mathrm{mg}^{-1}\left(\mathrm{k}_{\text {cat }}=216 \mathrm{~s}^{-1}\right)$, respectively, similar to values reported previously. ${ }^{21,32,37,38}$ For the red kidney bean enzyme the specific activity at $\mathrm{pH} 4.9$ and $\mathrm{pH} 6.2$ (optimum $\mathrm{pH}$ ) is $\sim 100 \mathrm{U} \mathrm{mg}^{-1}\left(\mathrm{k}_{\text {cat }}=180 \mathrm{~s}^{-1}\right)$ and $170 \mathrm{U} \mathrm{mg}^{-1}\left(\mathrm{k}_{\text {cat }}=312 \mathrm{~s}^{-1}\right)$, respectively, also in good agreement with previous studies. ${ }^{10}$ The kinetic parameters are summarised in Table 1. For both enzymes the $\mathrm{K}_{\mathrm{m}}$ values for the substrate $p$-NPP increase as the $\mathrm{pH}$ is increased, an observation which is likely to be due to the deprotonation of a histidine residue in the substrate binding pocket of the enzyme. ${ }^{16,39}$ 
The inhibitory effect of vanadate on the activity of red kidney bean PAP was determined at optimum $\mathrm{pH}(\mathrm{pH}$ 6.2). At that $\mathrm{pH}$ vanadate monomers tend to oligomerise in solution provided the total concentration of the tetraoxo anion is $\geq 0.25 \mathrm{mmol} \mathrm{L}^{-1} .{ }^{23}$ Since the monomeric form is the main inhibitor of $\mathrm{PAPs}^{23}$ it was essential to estimate the concentration of this species under conditions employed in the kinetic assays. Vanadium-51 $(99.75 \%$ natural abundance) NMR is a convenient method to measure the relative concentrations of vanadate species in solutions. ${ }^{40}$ Despite the $7 / 2$ spin, line widths for ${ }^{51} \mathrm{~V}$ are relatively narrow and are easily resolved. ${ }^{41}$ The ${ }^{51} \mathrm{~V}$ NMR (Figure 2), indicated that under the conditions applied in the kinetic assays the monomer concentration maximised at $\sim 0.6 \mathrm{mmol} \mathrm{L}^{-1}$. Total vanadate concentrations in the kinetic assays were chosen to yield monomer concentrations ranging from $10 \mu \mathrm{mol} \mathrm{L}^{-1}$ to $500 \mu \mathrm{mol} \mathrm{L}^{-1}$. Fitting the data in Figure 3 (equation 2) resulted in $\mathrm{K}_{\mathrm{ic}}=30 \mu \mathrm{mol} \mathrm{L}^{-1}$ (Table 2), indicating that vanadate acts as a moderately strongly binding competitive inhibitor. No accurate estimate of the inhibition constant could be obtained at $\mathrm{pH} 4.9$ due to the tighter binding $\left(\mathrm{K}_{\mathrm{i}}\right.$ $<10 \mu \mathrm{mol} \mathrm{L}^{-1}$ ) and the complex speciation of vanadate at this $\mathrm{pH}$. For pig PAP the inhibition by vanadate was assessed previously at $\mathrm{pH} 5.5,{ }^{23}$ resulting in a $\mathrm{K}_{\mathrm{i}}$ of 40 $\mu \mathrm{mol} \mathrm{L}{ }^{-1}$. In contrast to the red kidney bean enzyme, for pig PAP the inhibition mode appears to be non-competitive with $\mathrm{K}_{\mathrm{i}}=\mathrm{K}_{\mathrm{ic}}=\mathrm{K}_{\mathrm{iuc}}$. Furthermore, the same study has revealed that the substitution of the divalent iron by zinc reduces the inhibitory effect of vanadate $\left(\mathrm{K}_{\mathrm{i}}=360 \mu \mathrm{mol}\right.$ $\mathrm{L}^{-1}$ ) but not the mode of inhibition. ${ }^{23}$ Thus, the protein environments in the active sites of pig and red kidney bean PAPs, but not the metal ion compositions, are likely to be responsible for the different modes of inhibition observed. The results obtained for the red kidney bean enzyme resemble those obtained for the di- $\mathrm{Zn}^{\mathrm{II}}$ alkaline phosphatase from E. coli, where vanadate acts as a competitive inhibitor with $\mathrm{K}_{\mathrm{ic}}=12 \mu \mathrm{mol} \mathrm{L}^{-1}$ at $\mathrm{pH}$ 8.0..$^{25}$ The crystal structure of this enzyme, complexed with vanadate, has been solved and supports the hypothesis that vanadate is a suitable mimic of the proposed fivecoordinate phosphoryl transition state (Figure 1). Based on the similarity of the inhibition data it appears likely that red kidney bean PAP has a transition state similar to that observed in E. coli alkaline phosphatase. However, pig PAP may differ from these two enzymes based on the variation in the vanadate inhibition kinetics (noncompetitive binding of the inhibitor). Hence, subtle variations in the active site structures may have a significant effect on the formation of the transition state.

The inhibitory effect of fluoride was determined for pig and red kidney bean PAPs at $\mathrm{pH} 4.9$ and $\mathrm{pH} 6.2$ and the data were analysed by non-linear regression using equation 2 (Figure 4). For the pig enzyme the mode of inhibition changes from uncompetitive to non-competitive upon raising the $\mathrm{pH}$ (Table 3). A similar result has been reported for the $\mathrm{Fe}^{\mathrm{II}} \mathrm{Zn}^{\mathrm{II}}$ derivative of PAP from bovine spleen (Table 3). ${ }^{24}$ The

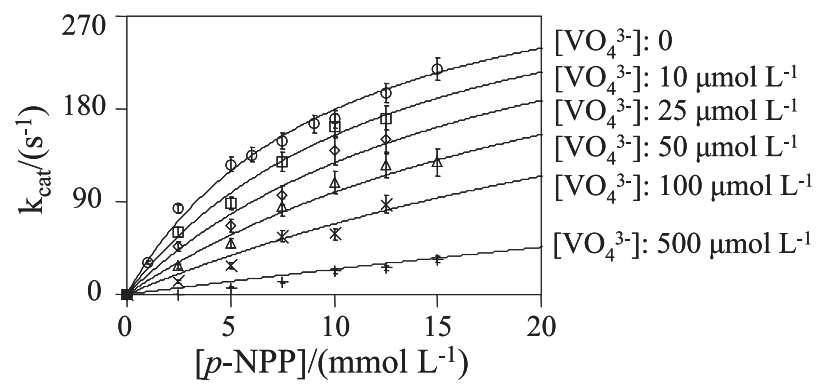

Figure 3. Steady-state inhibition of red kidney bean PAP by vanadate at $\mathrm{pH}$ 6.2. Vanadate concentrations ranged from 0 to $500 \mu \mathrm{mol} \mathrm{L}^{-1}$ (as indicated on the right side). Data was analysed by non-linear regression using equation 2.

Table 1. Kinetic parameters for pig and red kidney bean PAP at $\mathrm{pH} 4.9$ and 6.2

\begin{tabular}{lcccc}
\hline Parameter & \multicolumn{3}{c}{ Pig PAP } & \multicolumn{2}{c}{ Red kidney bean PAP } \\
\cline { 2 - 5 } & $\mathrm{pH} 4.9$ & $\mathrm{pH} 6.2$ & $\mathrm{pH} 4.9$ & $\mathrm{pH} 6.2$ \\
\hline $\mathrm{V}_{\text {max }} /\left(\mathrm{U} \mathrm{mg}^{-1}\right)$ & $635.3 \pm 14.9$ & $371.0 \pm 26.4$ & $98.6 \pm 7.2$ & $170.6 \pm 6.7$ \\
$k_{\text {cat }} / \mathrm{s}^{-1}$ & $370.6 \pm 8.7$ & $216.4 \pm 15.4$ & $180.7 \pm 13.1$ & $312.8 \pm 14.7$ \\
$\mathrm{~K}_{\mathrm{m}} /\left(\mathrm{mmol} \mathrm{L}^{-1}\right)$ & $3.7 \pm 0.2$ & $7.0 \pm 1.0$ & $2.6 \pm 0.5$ & $5.9 \pm 0.7$ \\
\hline
\end{tabular}

Table 2. Inhibition of pig and red kidney bean PAP by vanadate. $\mathrm{K}_{\mathrm{iuc}}$ and $\mathrm{K}_{\mathrm{ic}}$ are the dissociation constants for uncompetitive and competitive inhibition, respectively. "“" indicates that no inhibition could be detected. In the case of noncompetitive inhibition $\mathrm{K}_{\mathrm{iuc}}$ and $\mathrm{K}_{\mathrm{ic}}$ are of similar magnitude ${ }^{34}$

\begin{tabular}{lccc}
\hline & $\mathrm{pH}$ & $\mathrm{K}_{\text {iuc }}$ & $\mathrm{K}_{\text {ic }}$ \\
\hline Pig PAP & 5.5 & $40.0 \pm 5.0 \mu \mathrm{mol} \mathrm{L}^{-1}$ & $40.0 \pm 5.0 \mu \mathrm{mol} \mathrm{L}^{-1}$ \\
Red kidney bean PAP & 6.2 & - & $29.5 \pm 5.8 \mu \mathrm{mol} \mathrm{L}^{-1}$ \\
\hline
\end{tabular}

${ }^{\mathrm{a}}$ from reference 23 . 
observation of uncompetitive binding of the inhibitor at low $\mathrm{pH}$ indicates that fluoride only interacts with the enzymesubstrate (ES) complex. However, at higher $\mathrm{pH}$ fluoride can also bind to the free enzyme, competing with the substrate. The competitive binding site has previously been identified in terms of a terminal coordination to the divalent metal ion in the active site. ${ }^{24,42,43}$ The observation that metal ion substitutions in the divalent sites of pig and bovine PAP moderately affect the magnitude of the inhibition (but not its mode) is consistent with this assignment (Table 3). At lower $\mathrm{pH}$ the substrate binds tighter to the active site, most likely due to interactions between a positively charged histidine residue and the negatively charged phosphate group of the substrate. ${ }^{14-17,20}$ Consequently, fluoride is not an efficient competitor for interactions between the enzyme and the substrate, resulting in the observed uncompetitive mode of inhibition. Uncompetitive interactions between fluoride and $\mathrm{Fe}^{\mathrm{III}}$ are clearly demonstrated by the effect of metal ion substitutions on the $\mathrm{K}_{\text {iuc }}$ of bovine PAP (Table 3). The inhibition of the $\mathrm{Al}^{\mathrm{II}} \mathrm{Zn}^{\mathrm{II}}$ derivative of bovine PAP at low $\mathrm{pH}$ is greatly enhanced in comparison to the $\mathrm{Ga}^{\mathrm{III}} \mathrm{Zn}^{\mathrm{II}}$ and $\mathrm{Fe}^{\mathrm{III}} \mathrm{Zn}^{\mathrm{II}}$ derivatives, in agreement with the prediction that $\mathrm{Al}^{\mathrm{III}}$ is a harder acid than $\mathrm{Ga}^{\mathrm{III}}$ and $\mathrm{Fe}^{\mathrm{III}} \cdot{ }^{24}$ In principle, two possibilities for uncompetitive binding exist (Figure 5), (i) a terminal coordination of fluoride to the trivalent iron, or ( $\mathrm{ii}$ ) the formation of a $\mu$-fluoro complex, where the inhibitor bridges the two metal centres, thus displacing the $\mu$-hydroxo group.
Table 3. Inhibition of PAPs by fluoride. $\mathrm{K}_{\mathrm{iuc}}$ and $\mathrm{K}_{\mathrm{ic}}$ are the dissociation constants for uncompetitive and competitive inhibition, respectively. "-" indicates the absence of inhibition. In the case of noncompetitive inhibition $\mathrm{K}_{\mathrm{iuc}}$ and $\mathrm{K}_{\mathrm{ic}}$ are of similar magnitude. ${ }^{34}$ The metal ion compositions for pig and bovine PAP are indicated; red kidney bean PAP and human PAP have FeZn and FeFe centres, respectively. "Intact" and "cleaved" indicate the proteolytic state of human PAP $^{20}$

\begin{tabular}{|c|c|c|c|}
\hline Enzyme source & $\mathrm{pH}$ & $\mathrm{K}_{\text {iuc }} /\left(\mathrm{mmol} \mathrm{L}^{-1}\right)$ & $\mathrm{K}_{\mathrm{ic}} /\left(\mathrm{mmol} \mathrm{L}^{-1}\right)$ \\
\hline Pig (FeFe) & 4.9 & $0.12 \pm 0.01$ & - \\
\hline Pig $(\mathrm{FeZn})^{\mathrm{a}}$ & 4.9 & $0.20 \pm 0.09$ & - \\
\hline Pig (FeFe) & 6.2 & $1.84 \pm 0.40$ & $5.99 \pm 3.40$ \\
\hline Red kidney bean & 4.9 & - & $0.17 \pm 0.08$ \\
\hline Red kidney bean & 6.2 & - & $1.1 \pm 0.33$ \\
\hline Bovine $(\mathrm{FeZn})^{\mathrm{b}}$ & 5.0 & $0.20 \pm 0.03$ & - \\
\hline Bovine $(\mathrm{GaZn})^{\mathrm{b}}$ & 5.0 & $0.14 \pm 0.07$ & - \\
\hline Bovine $(\mathrm{AlZn})^{\mathrm{b}}$ & 5.0 & $0.003 \pm 0.0002$ & - \\
\hline Bovine $(\mathrm{FeZn})^{\mathrm{b}}$ & 6.5 & $2.05 \pm 0.10$ & $3.40 \pm 0.30$ \\
\hline Bovine $(\mathrm{FeFe})^{\mathrm{b}}$ & 6.5 & $4.44 \pm 0.50$ & $4.80 \pm 0.40$ \\
\hline Human (intact) ${ }^{c}$ & 3.3 & $0.19 \pm 0.02$ & $0.17 \pm 0.02$ \\
\hline Human (intact) ${ }^{c}$ & 4.9 & $0.50 \pm 0.05$ & $0.51 \pm 0.04$ \\
\hline hPAP (cleaved) $^{\mathrm{c}}$ & 3.3 & $0.16 \pm 0.01$ & $0.16 \pm 0.01$ \\
\hline hPAP $\left(\right.$ cleaved) ${ }^{\mathrm{c}}$ & 4.9 & $0.12 \pm 0.01$ & - \\
\hline
\end{tabular}

afrom reference 29; bfom reference 24; ' from reference 20.

From kinetic data alone these two possibilities cannot be distinguished, but EXAFS and resonance Raman spectroscopy have shown that the likely uncompetitive binding mode, at least in pig PAP, is the formation of the $\mu$ fluoro complex. ${ }^{29}$

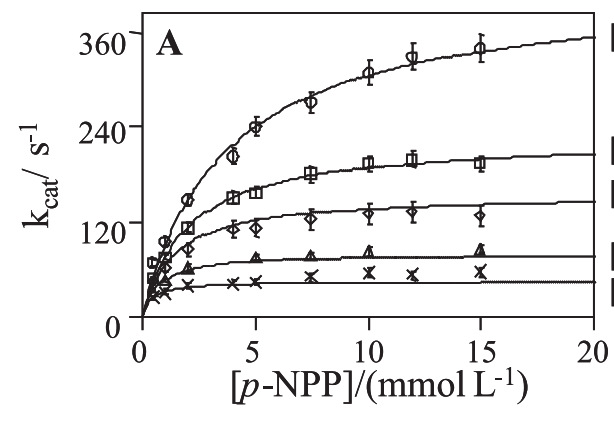

[F]: $0 \mathrm{mmol} \mathrm{L}^{-1}$

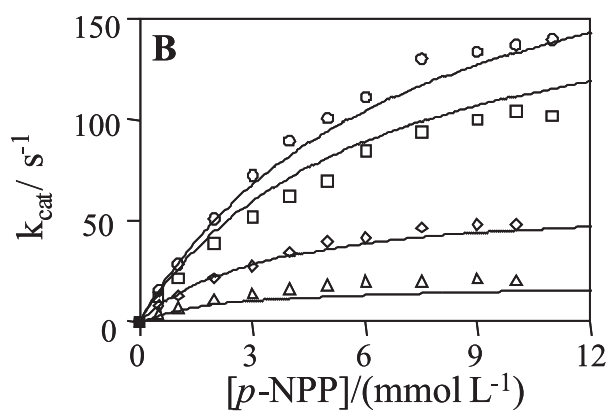
[F]: $1.0 \mathrm{mmol} \mathrm{L}^{-1}$
[F]: $0 \mathrm{mmol} \mathrm{L}^{-1}$ $[\mathrm{F}]: 0.5 \mathrm{mmol} \mathrm{L}^{-1}$

[F]: $5.0 \mathrm{mmol} \mathrm{L}^{-1}$

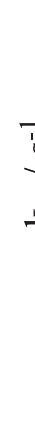

[F]: $20 \mathrm{mmol} \mathrm{L}^{-1}$

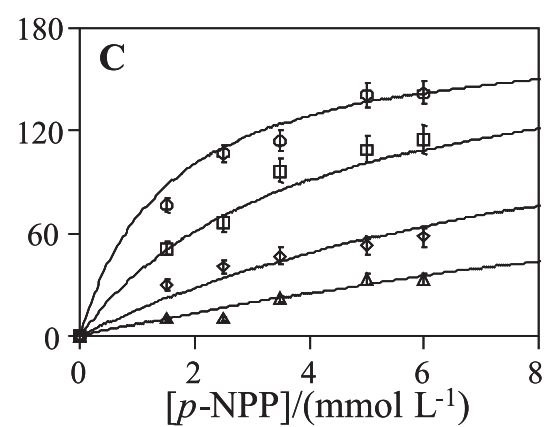

[F]: $0 \mathrm{mmol} \mathrm{L}^{-1}$

[F]: $0.25 \mathrm{mmol} \mathrm{L}^{-1}$

[F]: $1.0 \mathrm{mmol} \mathrm{L}^{-1}$

[F]: $2.5 \mathrm{mmol} \mathrm{L}^{-1}$

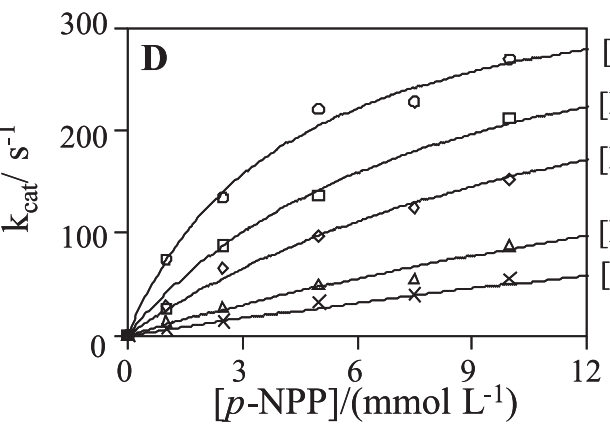

[F]: $0 \mathrm{mmol} \mathrm{L}^{-1}$

[F]: $0.5 \mathrm{mmol} \mathrm{L}^{-1}$

[F]: $1.0 \mathrm{mmol} \mathrm{L}^{-1}$

[F]: $2.5 \mathrm{mmol} \mathrm{L}^{-1}$

[F]: $7.5 \mathrm{mmol} \mathrm{L}^{-1}$

Figure 4. Steady-state inhibition of pig and red kidney bean PAP by fluoride. Fluoride concentrations ranged from 0 to $20 \mathrm{mmol} \mathrm{L}^{-1}$ (as indicated on the right side) for pig (A and B) and red kidney bean (C and D) PAP. Data were collected at pH 4.9 (A and C) and 6.2 (B and D) and analysed by non-linear regression using equation 2 . 


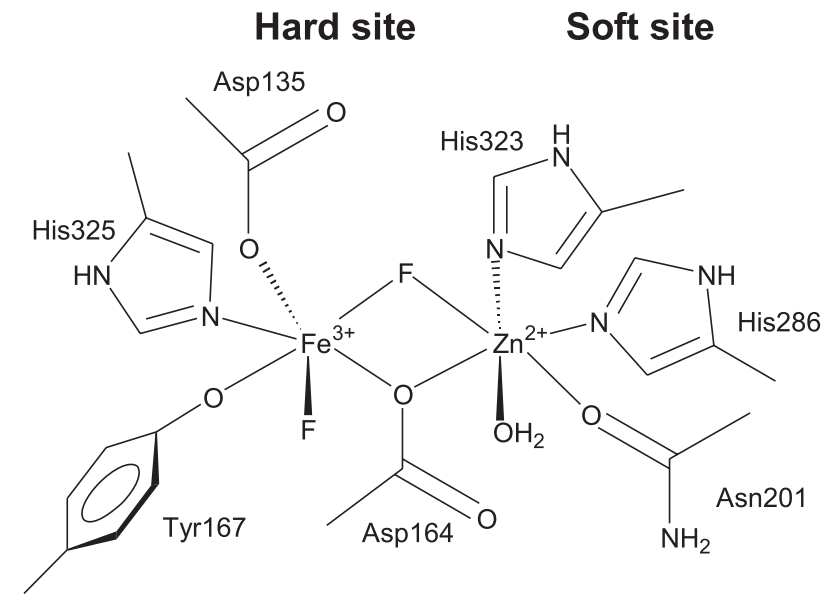

Figure 5. Schematic illustration of the active site of red kidney bean PAP. The two possible uncompetitive binding sites for the inhibitor fluoride are indicated.

The magnitude of the inhibition of red kidney bean PAP by fluoride is similar to that determined for both pig and bovine PAP, but the mode of inhibition is competitive, independent of $\mathrm{pH}$ (Table 3). In this respect the plant enzyme resembles intact human PAP, where the mode of fluoride inhibition is also not affected by the change in $\mathrm{pH}$, although for the human enzyme inhibition data were only collected at low $\mathrm{pH}$ values $\mathrm{pH} 3.3$ and $\mathrm{pH} 4.9$; Table 3).$^{20}$ Interestingly, the mode of fluoride inhibition in intact human PAP is non-competitive, contrasting both red kidney bean PAP and other mammalian PAPs (where the competitive inhibition site is inaccessible at low $\mathrm{pH}$; see above). Upon proteolytic cleavage human PAP displays fluoride inhibition kinetics at $\mathrm{pH} 4.9$ similar to those of pig and bovine PAP. ${ }^{20}$ It appears thus that the cleaved $\mathrm{Fe}^{\mathrm{III}} \mathrm{Fe}^{\mathrm{II}}$ form of human PAP is mechanistically related to pig and bovine PAP, while the intact form of this enzyme is similar to red kidney bean PAP although the apparent lack of fluoride binding to the enzyme-substrate complex in the red kidney bean enzyme suggests a mechanistic variation. Furthermore, the competitive nature of the inhibition of red kidney bean PAP by fluoride indicates that the inhibitor mainly interacts with the divalent metal ion (see above).

Fluoride has been shown to act as a slow binding inhibitor to a number of enzymes, including the bimetallic $\mathrm{Ni}^{\mathrm{II}}$ ureases from jack bean ${ }^{44}$ and Klebsiella aerogenes, ${ }^{36}$ and bovine PAP. ${ }^{24}$ In the presence of fluoride reaction progress curves of urease and bovine PAP are biphasic, indicating a gradual change from an initial uninhibited $\left(v_{\mathrm{i}}\right)$ to a final inhibited $\left(v_{\mathrm{f}}\right.$; steadystate) rate as fluoride binds. In both enzymes the rate of fluoride binding $\left(\mathrm{k}_{\mathrm{obs}}\right)$ depends on the concentration of the inhibitor. For $\mathrm{Fe}^{\mathrm{III}} \mathrm{Fe}^{\mathrm{II}}$ and $\mathrm{Fe}^{\mathrm{III}} \mathrm{Zn}^{\mathrm{II}}$ bovine PAP
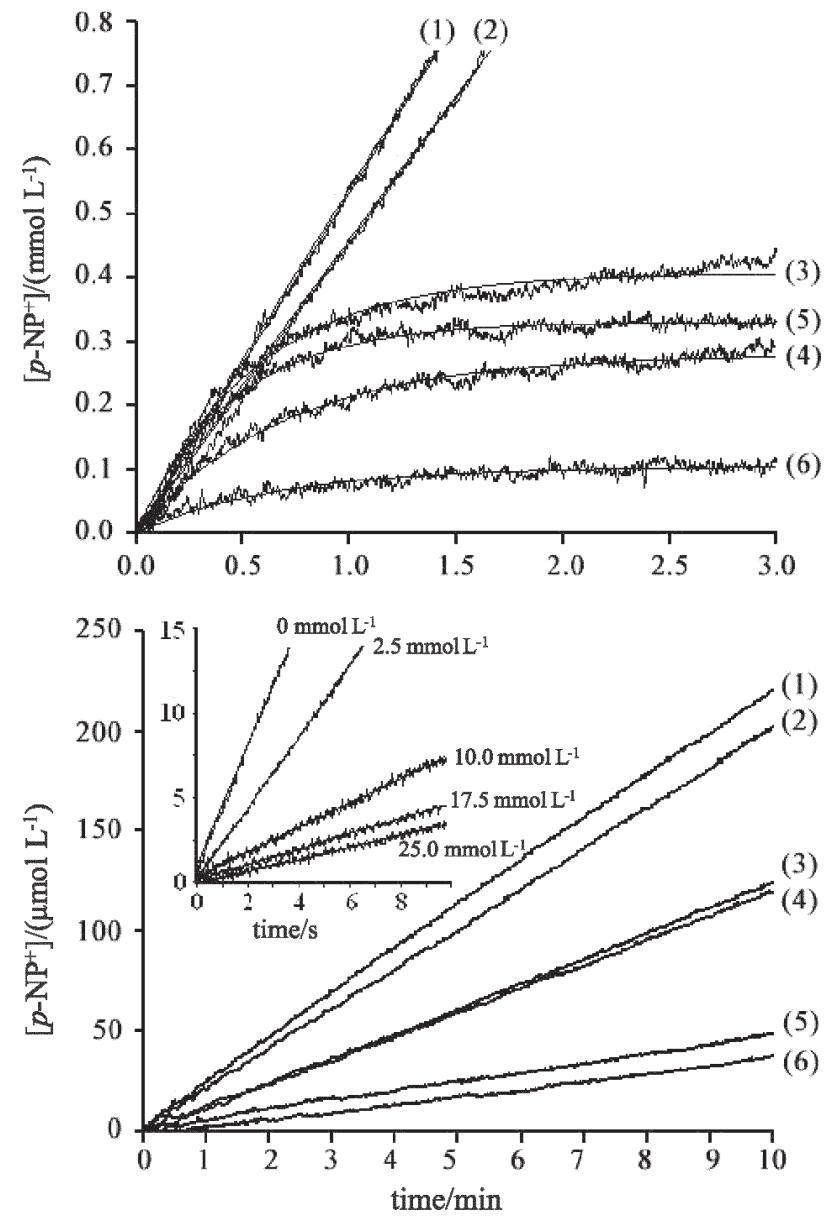

Figure 6. Inhibition of pig and red kidney bean PAPs by fluoride. (Top Panel) Pig PAP was incubated in the absence of fluoride for $0 \mathrm{~min}$ (trace 1) and $60 \mathrm{~min}$ (trace 2) at $25^{\circ} \mathrm{C}, \mathrm{pH} 4.9$, before the addition of $p$-NPP $(5$ $\left.\mathrm{mmol} \mathrm{L} \mathrm{L}^{-1}\right)$. Linear regression analysis of the progress curves revealed that only $5 \%$ of the activity was lost due to the incubation (Table 4). Reaction progress curves measured in the presence of $2.5 \mathrm{mmol} \mathrm{L}^{-1}$ (traces 3 and 4 with $0 \mathrm{~min}$ and $5 \mathrm{~min}$ incubation, respectively) and $10 \mathrm{mmol} \mathrm{L}^{-1}$ (traces 5 and 6 with $0 \mathrm{~min}$ and $60 \mathrm{~min}$ incubation, respectively) fluoride indicate biphasic behaviour. The data was analysed using equation 3 . (Bottom Panel) Red kidney bean PAP was incubated in the absence of fluoride for $0 \mathrm{~min}$ (trace 1) and $60 \mathrm{~min}$ (trace 2) at $25^{\circ} \mathrm{C}, \mathrm{pH} 6.2$, before the addition of $p$-NPP $\left(5 \mathrm{mmol} \mathrm{L}^{-1}\right)$. Linear regression analysis of the progress curves revealed that less than $5 \%$ of the activity was lost due to the incubation. Reaction progress curves measured in the presence of $2.5 \mathrm{mmol} \mathrm{L}^{-1}$ (traces 3 and 4 with $0 \mathrm{~min}$ and $5 \mathrm{~min}$ incubation, respectively) and $10 \mathrm{mmol} \mathrm{L}^{-1}$ (traces 5 and 6 with $0 \mathrm{~min}$ and 60 min incubation, respectively) fluoride indicate linear behaviour, and the data was analysed using linear regression (Table 4B) Inset: linear reaction progress curves were also measured in the initial $10 \mathrm{~s}$ after substrate addition with a stopped flow spectrophotometer for various concentrations of fluoride without preincubation. The linear behaviour indicates rapid binding of fluoride, leading to immediate inhibition.

$\mathrm{k}_{\mathrm{obs}}$ increases linearly with increasing fluoride concentrations at $\mathrm{pH} 5.0$, reaching a value of $\sim 0.12 \mathrm{~s}^{-1}$ and $\sim 0.25 \mathrm{~s}^{-1}$ at $\left[\mathrm{F}^{-}\right]=2 \mathrm{mmol} \mathrm{L}^{-1}$, respectively. ${ }^{24}$ The moderate variation in $\mathrm{k}_{\mathrm{obs}}$ upon metal ion substitution in the divalent site suggests that the observed slow binding of fluoride is mainly due to the interaction of 
Table 4. Data for the fluoride binding to pig (A) and red kidney bean (B) PAP. Note that a product formation rate of $1000 \mu \mathrm{mol}^{-1}$ min ${ }^{-1}$ and 20 $\mu \mathrm{mol} \mathrm{L} \mathrm{min}^{-1}$ correspond to a specific activity of $420 \mathrm{U} \mathrm{mg}^{-1}$ and $175 \mathrm{U} \mathrm{mg}^{-1}$ for the pig and red kidney bean enzymes, respectively

\begin{tabular}{|c|c|c|c|c|}
\hline $\begin{array}{l}\text { A } \\
{[\mathrm{F}] /\left(\mathrm{mmol} \mathrm{L}^{-1}\right)}\end{array}$ & Incubation time/ min & $k_{o b s} / \mathrm{s}^{-1}$ & $v_{i} /\left(\mu \mathrm{mol} \mathrm{L} \mathrm{L}^{-1} \min ^{-1}\right)$ & $v_{f} /\left(\mu \mathrm{mol} \mathrm{L}{ }^{-1} \min ^{-1}\right)$ \\
\hline 0 & 0 & - & $1213 \pm 9$ & $1213 \pm 9$ \\
\hline 0 & 60 & - & $1153 \pm 12$ & $1153 \pm 12$ \\
\hline 2 & 0 & $0.047 \pm 0.0005$ & $1043 \pm 10$ & $35.4 \pm 0.5$ \\
\hline 2 & 5 & $0.039 \pm 0.0004$ & $552 \pm 3$ & $27.4 \pm 0.2$ \\
\hline 10 & 0 & $0.042 \pm 0.0002$ & $870 \pm 24$ & $3.3 \pm 0.1$ \\
\hline 10 & 60 & $0.025 \pm 0.0004$ & $119 \pm 7$ & $6.5 \pm 0.3$ \\
\hline \multicolumn{5}{|l|}{ B } \\
\hline$[\mathrm{F}] /\left(\mathrm{mmol} \mathrm{L}^{-1}\right)$ & Incubation time/ $\mathrm{min}$ & $v_{f} /\left(\mu \mathrm{mol} \mathrm{L} \mathrm{L}^{-1} \min ^{-1}\right)$ & & \\
\hline 0 & 0 & $21.2 \pm 0.05$ & & \\
\hline 0 & 60 & $20.0 \pm 0.02$ & & \\
\hline 2 & 0 & $12.4 \pm 0.01$ & & \\
\hline 2 & 5 & $12.5 \pm 0.01$ & & \\
\hline 10 & 0 & $4.8 \pm 0.01$ & & \\
\hline 10 & 60 & $4.5 \pm 0.01$ & & \\
\hline
\end{tabular}

the inhibitor with the trivalent metal ion. The observation that the rate of fluoride binding drastically increases upon replacing $\mathrm{Fe}^{\mathrm{III}}$ by $\mathrm{Al}^{\mathrm{III}}$ and $\mathrm{Ga}^{\mathrm{III}}$ is in agreement with this hypothesis. ${ }^{24}$ In this study the $\mathrm{Fe}^{\mathrm{III}} \mathrm{Fe}^{\mathrm{II}}$ pig PAP reaction was monitored at $\mathrm{pH} 4.9$ (optimal $\mathrm{pH}$ for activity) at several fluoride concentrations (Figure 6). In the presence of $2 \mathrm{mmol} \mathrm{L}^{-1}$ inhibitor $\mathrm{k}_{\mathrm{obs}}$ is $0.047 \mathrm{~s}^{-1}$ (Table 4), approximately $40 \%$ of the value obtained for bovine PAP, suggesting a conserved mode of interaction between enzyme and inhibitor in animal PAPs. This is not surprising based on the similarity of the inhibition constants determined for the two enzymes (Table 3). An intriguing observation is the fact that the pre-incubation of the enzyme with fluoride does not greatly affect the final steady-state rate $\left(v_{\mathrm{f}}\right)$ of the reaction, but the initial rates are reduced (Table 4). A similar result has been reported for $K$. aerogenes urease and has been interpreted in terms of this enzyme existing in two distinct conformations in the resting state, one with low and one with high affinity for fluoride. ${ }^{36}$ It is thus possible that the resting state of pig PAP occurs in at least two distinct conformations that co-exist in equilibrium. Addition of the substrate shifts this equilibrium in favour of the state with higher fluoride affinity. The existence of at least two distinct conformations in the resting state may explain catalytic variations observed between various mammalian PAPs (e.g. Table 3), and may be associated with the mobile repression loop in the vicinity of the active site. ${ }^{18,20,28}$

Fluoride inhibition of red kidney bean PAP appears instantaneous (Figure 6), within the technical limitations of the stopped-flow instrument, indicating a vastly increased $\mathrm{k}_{\mathrm{obb}}$. Also, prolonged incubation with fluoride did not affect the rate (Table 4). The loss of activity upon incubation for $60 \mathrm{~min}$ is small and comparable in the inhibited and uninhibited enzyme (Figure 6). Hence, in agreement with the results above red kidney bean PAP interacts in a distinctly different manner with fluoride than mammalian PAPs. The rapid establishment of inhibition is consistent with fluoride binding predominantly to the divalent metal ion (rapid ligand exchange) and agrees with the observed competitive inhibition (Table 3).

\section{Conclusions}

PAPs display a high degree of structural similarity in their active sites, and consequently their catalytic reactions are anticipated to employ the same mechanism. Interestingly, variations are observed in the interactions between representatives of these enzymes and vanadate and fluoride. Since these anions have been proposed to mimic the transition state of phosphorolytic enzymes, ${ }^{25}$ or displace the reaction-initiating nucleophile, ${ }^{1,24,29}$ the kinetic variations between red kidney bean and mammalian PAPs indicate that these enzymes employ alternative mechanistic strategies. Specifically, the precise nature of their transition states and the identity of their nucleophiles may vary. A structural understanding of these differences may be particularly significant in terms of the design and development of site-specific inhibitors for PAPs. Considering the crucial role(s) mammalian PAPs have in bone metabolism such inhibitors are anticipated to be promising lead compounds in the development of new anti-osteoporotic chemotherapeutics. Efforts towards these aims are currently in progress in our group. 


\section{Acknowledgments}

This work was funded by a grant from the Australian Research Council (DP0558652). The authors would like to thank Ms Eleanor Leung and Ms Fernanda Ely for their assistance.

\section{References}

1. Mitić, N.; Smith, S. J.; Neves, A.; Guddat, L.W.; Gahan, L.R.; Schenk, G.; Chem. Rev. 2006, 106, 3338.

2. Bull, H.; Murray, P. G.; Thomas, D.; Fraser, A. M.; Nelson, P. N.; J. Clin. Pathol.-Mol. Pathol. 2002, 55, 65.

3. Antanaitis, B. C.; Aisen, P.; Lilienthal, H. R.; J. Biol. Chem. 1983, 258, 3166.

4. Yang, Y.; McCormick, J. M.; Solomon, E. I.; J. Am. Chem. Soc. 1997, 119, 11834.

5. Oddie, G. W.; Schenk, G.; Angel, N. Z.; Walsh, N.; Guddat, L. W.; de Jersey, J.; Cassady, A. I.; Hamilton, S. E.; Hume, D. A.; Bone 2000, 27, 575.

6. Schenk, G.; Guddat, L. W.; Ge, Y.; Carrington, L. E.; Hume, D. A.; Hamilton, S.; de Jersey, J.; Gene 2000, 250, 117.

7. Schenk, G.; Korsinczky, M. L. J.; Hume, D. A.; Hamilton, S.; de Jersey, J.; Gene 2000, 255, 419.

8. Flanagan, J. U.; Cassady, A. I.; Schenk, G.; Guddat, L. W.; Hume, D. A.; Gene 2006, 377, 12.

9. Bernhardt, P. V.; Schenk, G.; Wilson, G. J.; Biochemistry 2004, 43, 10387.

10. Beck, J. L.; McConaghie, L. A.; Summors, A. C.; Arnold, W. N.; de Jersey, J.; Zerner, B.; Biochim. Biophys. Acta 1986, 869, 61.

11. Schenk, G.; Ge, Y.; Carrington, L. E.; Wynne, C. J.; Searle, I. R.; Carroll, B. J.; Hamilton, S.; de Jersey, J.; Arch. Biochem. Biophys. 1999, 370, 183.

12. Durmus, A.; Eicken, C.; Spener, F.; Krebs, B.; Biochim. Biophys. Acta, Protein Struct. Mol. Enzymol. 1999, 1434, 202.

13. Sträter, N.; Klabunde, T.; Tucker, P.; Witzel, H.; Krebs, B.; Science 1995, 268, 1489.

14. Klabunde, T.; Sträter, N.; Fröhlich, R.; Witzel, H.; Krebs, B.; J. Mol. Biol. 1996, 259, 737.

15. Guddat, L. W.; McAlpine, A. S.; Hume, D. A.; Hamilton, S.; de Jersey, J.; Martin, J. L.; Structure 1999, 7, 757.

16. Schenk, G.; Gahan, L. R.; Carrington, L. E.; Mitić, N.; Valizadeh, M.; Hamilton, S. E.; de Jersey, J.; Guddat, L. W.; Proc. Natl. Acad. Sci. U. S. A. 2005, 102, 273.

17. Lindqvist, Y.; Johansson, E.; Kaija, H.; Vihko, P.; Schneider, G.; J. Mol. Biol. 1999, 291, 135.

18. Sträter, N.; Jasper, B.; Scholte, M.; Krebs, B.; Duff, A. P.; Langley, D. B.; Han, R.; Averill, B. A.; Freeman, H. C.; Guss, J. M.; J. Mol. Biol. 2005, 351, 233.

19. Ljusberg, L.; Ek-Rylander, B.; Andersson, G.; Biochem. J. 1999, $343,63$.
20. Mitić, N.; Valizadeh, M.; Leung, E. W. W.; de Jersey, J.; Hamilton, S.; Hume, D. A.; Cassady, A. I.; Schenk, G.; Arch. Biochem. Biophys. 2005, 2, 154.

21. Valizadeh, M.; Schenk, G.; Nash, K.; Oddie, G. W.; Guddat, L. W.; Hume, D. A.; de Jersey, J.; Burke, T. R.; Hamilton, S.; Arch. Biochem. Biophys. 2004, 424, 154.

22. Moss, D. W.; Raymond, F. D.; Wile, D. B.; Crit. Rev. Clin. Lab. Sci. 1995, 32, 431.

23. Crans, D. C.; Simone, S.; Holz, R. C.; Que, L., Jr.; Biochemistry 1992, 31, 11731.

24. Pinkse, M. W.; Merkx, M.; Averill, B. A.; Biochemistry 1999, 38, 9926.

25. Holtz, K. M.; Stec, B.; Kantrowitz, E. R.; J. Biol. Chem. 1999, 274, 8351.

26. Cama, E.; Pethe, S.; Boucher, J.; Han, S.; Emig, F. A.; Ash, D. E.; Biochemistry 2004, 43, 8987.

27. Funhoff, E.G.; Bollen, M.; Averill, B. A.; J. Inorg. Biochem. 2005, 272, 2968.

28. Funhoff, E.G.; de Jongh, T. E.; Averill, B. A.; J. Biol. Inorg. Chem. 2005, 10, 550.

29. Wang, X.; Ho, R. Y. N.; Whiting, A. K.; Que, L., Jr.; J. Am. Chem. Soc. 1999, 121, 9235.

30. Lahiri, S. D.; Zhang, G.; Dunaway-Mariano, D.; Allen, K. N.; Science 2003, 299, 2067.

31. Davies, D. R.; Hol, W. G. J.; FEBS Lett. 2004, 577, 315.

32. Campbell, H. D.; Dionysius, D. A.; Keough, D. T.; Wilson, B. E.; de Jersey, J.; Zerner, B.; Biochem. Biophys. Res. Commun. 1978, 82, 615.

33. Truong, N. T.; Naseri, J. I.; Vogel, A.; Rompel, A.; Krebs, B.; Arch. Biochem. Biophys. 2005, 440, 38.

34. Segel, I. H.; Enzyme Kinetics: Behavior and Analysis of Rapid Equilibrium and Steady-State Enzyme Systems, library ed., Wiley: New York, 1993.

35. Cha, S.; Biochem. Pharmacol. 1975, 24, 2177.

36. Todd, M. J.; Hausinger, R. P.; Biochemistry 2000, 39, 5389.

37. Schlosnagle, D. C.; Bazer, F. W.; Tsibris, J. C.; J. Biol. Chem. 1974, 249, 7574.

38. Beck, J. L.; Keough, D. T.; de Jersey, J.; Zerner, B.; Biochim. Biophys. Acta 1984, 791, 357.

39. Merkx, M.; Pinkse, M. W.; Averill, B. A.; Biochemistry 1999, 38, 9914.

40. Butler, A.; Eckert, H.; J. Am. Chem. Soc. 1989, 111, 2802.

41. Crans, D. C.; Shin, P. K.; Inorg. Chem. 1988, 27, 1797.

42. Aquino, M. A. S.; Lim, J.-S.; Sykes, A. G.; J. Chem. Soc. Dalton Trans. 1994, 429.

43. Twitchett, M. B.; Schenk, G.; Aquino, M. A. S.; Yiu, D. T.; Lau, T.-C.; Sykes, A. G.; Inorg. Chem. 2002, 41, 5787.

44. Dixon, N. E.; Blakeley, R. L.; Zerner, B.; Can. J. Biochem. 1980, 58,481 .

Received: May 26, 2006

Published on the web: November 7, 2006 